\title{
Influence of Nutrient Management on the Growth, Yield and Nutrient Uptake of Wheat (Triticum aestivum. L) in Lateritic Belt of West Bengal
}

\author{
Samata Mohanta $^{1 *}$, Mahua Banerjee ${ }^{2}$ and Tanmoy Shankar ${ }^{3}$ \\ ${ }^{1}$ Department of Agriculture \& Farmer's Empowerment, Govt. of Odisha, \\ Anandapur-758020, India \\ ${ }^{2}$ Palli Siksha Bhavana, Visva-Bharati, Sriniketan- 731204, Birbhum, West Bengal India \\ ${ }^{3}$ Department of Agronomy, M.S. Swaminathan School of Agriculture, Centurion University \\ Technology and Management, Paralakhemundi- 761 211, Odisha, India \\ *Corresponding author
}

\section{A B S T R A C T}

\section{Keywords \\ Wheat, nutrient management, growth ,yield, uptake}

\section{Article Info}

Accepted:

18 May 2020

Available Online:

10 June 2020
The present investigation entitled to evaluate the effect of nutrient management on the growth and productivity of wheat (Triticum aestivum L.) in the red and lateritic belt of West Bengalwas carried out during rabi season of 2011-12 at Agricultural farm of Palli Siksha Bhavana, VisvaBharati, Sriniketan (West Bengal). Integrated use of biofertilizers in combination with the chemical fertilizer and their proper management for better productivity and economics is very essential. Keeping, these facts in perspective, the present investigation were taken up. The experiment consisted of the five levels of fertilizer i.e. control, $50 \% \mathrm{RDF}, 75 \% \mathrm{RDF}, 100 \%$ RDF and $125 \%$ RDF and four levels of biofertilizers viz. no biofertilizers, Azotobacter, Phosphorus solubilizing bacteria (PSB) and combined application of Azotobacter and PSB thus making twenty treatment combinations which were replicated thrice and was laid out in factorial randomized block design (FRBD). The Recommended dose of fertilizer (RDF) was 100:50:50 kg/ha of $\mathrm{N}: \mathrm{P}_{2} \mathrm{O}_{5}: \mathrm{K}_{2} \mathrm{O}$. The maximum values for growth parameters like plant height, dry matter accumulation and leaf area index were observed in $125 \%$ RDF and Azotobacter + PSB and similar effect was observed yield attributes and yield. The total nutrient uptake of wheat was recorded highest in the $125 \% \mathrm{RDF}+$ Azotobactor + Phosphate Solubilizing and The lowest value in recorded in Control. This indicated that the wheat crop responded upto $125 \%$ RDF and combined application of Azotobacter and PSB proved superior over application of Azotobacter only but was statistically at par in most of the cases with application of PSB alone.

\section{Introduction}

Among the food grains, wheat is the leading cereal crop of the world. It is cultivated in 227 million ha producing 682 million tonnes with a productivity of $30.0 \mathrm{q} / \mathrm{ha}$. In India, it is the second important staple food crop next to rice and cultivated over an area of 30.2 mha with a total production of $93.5 \mathrm{mt}$ and productivity of $29.4 \mathrm{q} / \mathrm{ha}$ (Anonymous, 2018). Recently, in West Bengal, wheat cultivation is taken up in an area of 0.315 mha producing $0.846 \mathrm{mt}$ with the productivity of $26.80 \mathrm{q} / \mathrm{ha}$. This productivity is lower than the national average and considerably less than other leading wheat growing states having longer 
winter season, provision of irrigation facilities, better nutrient, weed and crop management practices. Being a winter cereal, productivity of wheat is more stable than rice and wheat requires only $20 \%$ of water requirement of rice. In future decades, in order to improve the food grain production status, more emphasis should be given on wheat. The nutrient requirement of a crop is met by the external application of chemical or biofertilizers as amendment, seed/soil inoculation with biofertilizers or by foliar application. Besides these, a part of the crop nutrient demand is also met by the available soil nutrients.

The major challenge for agriculture increasing demands for sustainable. But decline of soil fertility and negligence of plant nutrients have made this task more difficult (Gruhn and Goletti, 1998; Prasad, 2008). The key components of this approach were described, the roles and responsibilities of various factors, including farmers and institutions were delineated and recommendations for improving the management of plant nutrients and soil fertility at present therefore, it is also necessary for soil health. Continuous use of chemical fertilizer results in decline in yield and soil fertility and increases environmental pollution (Virmani, 1994). Hence, there is great need for supplementing the plant nutrients with eco-friendly for enhanced sustainability.

One of the challenges of globalization and green revolution is not only to increase the yield but is also to improve the nutritional quality of product so that it matches global standards. The world over is undergoing a shift from inorganic conventional farming towards organic eco-friendly farming methods. It has a very important role in deciding the optimum activity of the microorganisms. Such practices could play a major role in the future. National Biofertilizer
Development Centre has estimated the requirement of Biofertilizers to extent of $507032 \mathrm{mt}$ of $\mathrm{N}_{2}$ fixing, $255340 \mathrm{mt}$ of Phosphate mobilizing Bacteria. Thus, we could ensure the optimum productivity and healthy returns under Integrated Nutrient Management system through increased use of biofertilizer. This would help in economic benefit and the farmers realize the worth, potential, long term commercial benefits (Sepat et al., 2010).

\section{Materials and Methods}

Field experiments were conducted during rabi season of 2011-12 for studying the effect of nutrient management on the growth and productivity of wheat (Triticum aestivum L.) in the red and lateritic belt of West Bengal. This chapter briefly presents the experimental details regarding the materials used, the observations taken and techniques employed during the course of this investigation. The farm is situated at $23^{0} 39^{\prime} \mathrm{N}$ latitude and $87^{\circ} 42^{\prime}$ E longitude with an average altitude of $58.9 \mathrm{~m}$ above mean sea level under sub-humid, semi arid region of West Bengal. The experiment consisted of the five levels of fertilizer i.e. control, $50 \%$ RDF, $75 \%$ RDF, $100 \%$ RDF and $125 \%$ RDF and four levels of biofertilizers viz. no biofertilizers, Azotobacter, Phosphorus solubilizing bacteria (PSB) and combined application of Azotobacter and PSB thus making twenty treatment combinations which were replicated thrice and was laid out in factorial randomized block design (FRBD). Sonalika variety was taken as a plant material. A presowing irrigation was given to the experimental plot for field preparation. At optimum moisture condition, the land was first ploughed thoroughly cross wise for two times with tractor drawn harrow and final land preparation with mould board plough thoroughly for obtaining good tilth followed by planking. 
After that, the land was free from clods and all stubbles of previous crops were removed. After levelling, the field was laid out properly by making bund in each channel for irrigation as well as drainage. The recommended fertilizer (NPK) dose for the wheat crop was $\mathrm{N}, \mathrm{P}_{2} 0_{5}$, and $\mathrm{K}_{2} \mathrm{O} @ 100: 50: 50 \mathrm{~kg} / \mathrm{ha}$. The fertilizers were applied in the plot as per treatments. As per treatments, during the land preparation, $1 / 2$ of total $\mathrm{N}$ and full dose of $\mathrm{P}_{2} \mathrm{O}_{5}$ and $\mathrm{K}_{2} \mathrm{O}$ were applied to the crop as basal application. The remaining $1 / 2 \mathrm{~N}$ was top dressed at 21 DAS and 50 DAS. Culture of phosphate solubilizing bacteria (PSB) containing clay based Bacillus polymyxa and free living $\mathrm{N}$ fixing bacterial culture of charcoal based Azotobacter brasiliense and each seed has a layer of the aforesaid bacteria then the PSB inoculant was treated on the outer layer of the seeds. The inoculant slurry was poured on it and was mixed with the seed uniformly. The inoculated seed was air-dried in shade and used for sowing. The crop was sown in row spaced at $22.5 \mathrm{~cm}$. The second row on either side of the net plot was used for destructive sampling. The non destructive observations were generally based on 5 randomly selected plants. The chemical analysis of plant and seed was carried out with standard laboratory practices. The analysis of variance method (Cochran and Cox, 1977) was followed to statistically analyse the various data. The significance of different source of variations was tested by "Error Mean Square Method" of Fisher Snedecor's ' $F$ ' test at probability level 0.05 .

\section{Results and Discussion}

\section{Growth attributes}

The growth attribute of wheat statically analysed and presented in Table 1.The highest plant height was recorded in $125 \%$ RDF at harvesting stages of crop which was significantly higher than all other treatments except $75 \%$ RDF and $100 \%$ RDF. The least plant height was observed when there was no fertilizer and biofertilizer applied. However, $\mathrm{PSB}+$ Azotobacter recorded maximum the plant height of wheat which was significantly higher and followed by PSB and Azotobacter at the same stages of crop.The lowest total dry matter accumulation was recorded where no application of both biofertilizer and fertilizer. the highest dry matter accumulation was noticed in $125 \%$ RDF which significantly higher than all other the treatments and PSB+ Azotobacter recocored maximum value and statistically at par with PSB and Azotobacter. The seed treatment with combine application of biofertilizer i.e PSB + Azotobacter recorded highest Leaf Area Index under $125 \%$ $\mathrm{RDF}$ at 60 DAS which was significantly higher than all other combination. The lowest Leaf Area Index was recorded when no application of both fertilizer and biofertilizer and with No fertilizer +PSB, No fertilizer + PSB + Azotobacter at 60 DAS. Secretion of vitamins and amino acids, auxins, and fixing atmospheric nitrogen by Azotobacter and Azospirillum are among the direct mechanisms of increasing root development and plant growth These results are in conformity with the works reported by Khavazi et al., 2005, Akbari et al., 2007 and Singh et al., 2020.

\section{Yield attribute}

Different levels of fertilizers and biofertilizers treatments significantly influenced in effective tillers $/ \mathrm{m}^{2}$, Grains/Ear-head, Ear Weight, Ear Length and test weight (Table 2). All the yield attributes was influenced by the levels of fertilizer application were found to increase the effective tillers $/ \mathrm{m}^{2}$, Grains/Earhead, Ear Weight, Ear Length and test weight significantly over control (no biofertilizers and fertilizer application). The highest yield attributes was recorded in $125 \%$ RDF which is significantly higher than all other treatment. 
The lowest observation was found where no fertilizer applied. In contest of biofertilizers gave highest recorded in combine application of PSB +Azotobacter. The lowest were observed with no bio fertilizer application which was statistically at par with PSB application. Different levels of fertilizer treatments (50\%RDF, 75\%RDF, $100 \% \mathrm{RDF}$ and $125 \% \mathrm{RDF}$ ) significantly influenced the test weight. All the levels of fertilizer applications were found to increase the Test weight significantly over control (no fertilizer application). The highest test weight (45.2gm) was recorded in $125 \%$ RDF which was significantly higher than all other treatments. The lowest test weight (38.7) was observed when there was no fertilizer application.Test weight of wheat was significantly influenced by the application of bio-fertilizers like PSB, Azotobacter, PSB + Azotobacter. The highest test weight $(42.5 \mathrm{gm})$ was recorded with combine application of both PSB and Azotobacter which was significantly higher than no biofertilizer application. The lowest test weight (40.9) was observed with no bio fertilizer application (Singh et al., 2018) and Singh et al., 2020).

\section{Yield}

Seed inoculation with biofertilizers along with different chemical fertilizers significantly increased the grain yield ( $t / h a)$ of wheat presented in Table 3. Different levels of fertilizer treatments $(50 \% \mathrm{RDF}, 75 \% \mathrm{RDF}$, $100 \% \mathrm{RDF}$ and $125 \% \mathrm{RDF}$ ) significantly influenced the grain yield (t/ha). All the levels of fertilizer application were found to increase the grain yield ( $\mathrm{t} / \mathrm{ha}$ ) significantly over control (no fertilizer application). The highest grain yield (3.28t/ha) was recorded in $125 \% \mathrm{RDF}$ which was significantly higher than all other treatments. The lowest grain yield $(0.73 \mathrm{t} / \mathrm{ha})$ was observed when there was no fertilizer application. There was increase in grain yield of $35 \%, 60 \%, 70.7 \%, 77.7 \%$ over no fertilizer application due to application of $50 \% \mathrm{RDF}$, $75 \% \mathrm{RDF}, \quad 100 \% \mathrm{RDF}$ and $125 \% \mathrm{RDF}$ respectively. Grain yield ( $t / h a)$ of wheat was significantly influenced by the application of bio-fertilizers like PSB, Azotobacter, PSB + Azotobacter.

The highest grain yield (2.19t/ha) was recorded in combine application of both PSB and Azotobacter. The lowest grain yield (1.62t/ha) was observed with no bio fertilizer application. There was increase in grain yield of $17 \%, 18 \%$ and $26 \%$ over no bio fertilizer application due to application of PSB, Azotobacter, PSB+Azotobacter respectively. Straw yield ( $t / h a)$ of wheat was significantly influenced by the application of bio-fertilizers like PSB, Azotobacter,PSB+Azotobacter.

The highest straw yield (3.92t/ha) was recorded in combine application of both PSB and Azotobacter. The lowest straw yield $(1.19 \mathrm{t} / \mathrm{ha})$ was observed with no bio fertilizer application which was statistically at par with No fertilizer + PSB. There was increase in straw yield of $2.3 \%, 16.1 \%$ and $19.6 \%$ over no bio fertilizer application due to application of PSB, Azotobacter and PSB+Azotobacter respectively.

The highest harvest index (45.1) was recorded in $125 \%$ RDF which was significantly higher than all other treatments. The lowest harvest index was observed when there was no fertilizer application which was statistically at par with 50\% RDF, 75\% RDF and $100 \%$ RDF. Harvest index of wheat was significantly influenced by the application of bio-fertilizers like PSB, Azotobacter, PSB + Azotobacter. The highest harvest index (41.4) was recorded in combine application of both PSB +Azotobacter application. The lowest harvest index (36.1 and 38.2) was observed with no fertilizers and biofertilizer application respectively (Kaushik et al., 2012 and Sikarwar et al., 2020). 


\section{Nutrient uptake}

The data pertaining to the total nutrient uptake in wheat was presented in Table 4. The data revealed that the highest total $\mathrm{N}$, Pand $\mathrm{K}$ uptake was 87.1, 24.5 and $63.8 \mathrm{~kg} / \mathrm{ha}$ respectively was recorded in $125 \% \mathrm{RDF}$ which was significantly higher than all other treatments. The lowest value for total N, P and $\mathrm{K}$ uptake of wheat were observed when there was no application of biofertilizers and chemical fertilizers applied. The significantly influenced by the application of bio-fertilizers like PSB, Azotobacter and combine application of PSB and Azotobacter. The total N, P and K uptake was highest (60.7, 16.1 and
$46.7 \mathrm{~kg} / \mathrm{ha}$ respectively) was recorded with combine application of PSB + Azotobacter.

Jakhar et al., (2005) reported that the Increases in total $\mathrm{N}, \mathrm{P}$ and $\mathrm{K}$ uptake were 8.5, 7.3 and $8.4 \%$ with Azotobacter chroococcum, and 10.1, 7.7 and $8.1 \%$ with Azospirillum brasilense, respectively, over no inoculation. The uptake of $\mathrm{N}$ by grains and straw, and the total $\mathrm{N}$ uptake increased with the increase in the $\mathrm{N}$ rate up to $150 \mathrm{~kg} / \mathrm{ha}$. The application of 125 and $150 \mathrm{~kg} \mathrm{~N} / \mathrm{ha}$ increased the total $\mathrm{P}$ uptake by 5.5 and $8.6 \%$, as well as the total $\mathrm{K}$ uptake by 6.0 and $9.2 \%$, respectively, over $100 \mathrm{~kg} \mathrm{~N} / \mathrm{ha}$ (Rathore and Sharma,2009).

Table.1 Effect nutrient management on growth attribute of wheat

\begin{tabular}{|c|c|c|c|}
\hline \multirow[t]{2}{*}{ Treatments } & \multicolumn{3}{|c|}{ Growth attributes } \\
\hline & $\begin{array}{l}\text { Plant height (cm) } \\
120 \text { DAS }\end{array}$ & $\begin{array}{c}\text { Dry matter } \\
\text { accumulation } \\
\left(\mathrm{gm}^{-2}\right) 120 \text { DAS }\end{array}$ & $\begin{array}{c}\text { Leaf area index } 60 \\
\text { DAS }\end{array}$ \\
\hline \multicolumn{4}{|c|}{ Fertilizer } \\
\hline No fertilizer & 56.8 & 151.8 & 0.8 \\
\hline $50 \%$ RDF & 68.2 & 236.8 & 1.6 \\
\hline 75\% RDF & 74.2 & 376.8 & 2.4 \\
\hline $100 \%$ RDF & 74.0 & 509.6 & 3.0 \\
\hline $125 \%$ RDF & 76.1 & 550.8 & 3.6 \\
\hline $\operatorname{SEm}( \pm)$ & 0.8 & 5.2 & 0.1 \\
\hline $\mathrm{CD}(\mathbf{P}=\mathbf{0 . 0 5})$ & 2.3 & 14.9 & 0.2 \\
\hline \multicolumn{4}{|c|}{ Biofertilizer } \\
\hline No Bio fertilizer & 68.4 & 356.8 & 2.1 \\
\hline PSB & 69.7 & 384.2 & 2.1 \\
\hline Azo & 69.7 & 428.1 & 2.3 \\
\hline PSB+Azo & 71.7 & 473.1 & 2.6 \\
\hline $\operatorname{SEm}( \pm)$ & 0.7 & 4.6 & 0.1 \\
\hline $\mathrm{CD}(\mathbf{P}=\mathbf{0 . 0 5})$ & 2.1 & 13.3 & 0.1 \\
\hline
\end{tabular}


Table.2 Effect nutrient management on yield attribute of wheat

\begin{tabular}{|c|c|c|c|c|c|}
\hline \multirow[t]{2}{*}{ Treatments } & \multicolumn{4}{|c|}{ Yield attributes } & \multirow[b]{2}{*}{$\begin{array}{c}\text { Test } \\
\text { weight } \\
\text { (gm) }\end{array}$} \\
\hline & $\begin{array}{l}\text { Effective } \\
\text { tillers } / \mathbf{m}^{2}\end{array}$ & $\begin{array}{c}\text { Grains/Ear- } \\
\text { head }\end{array}$ & $\begin{array}{c}\text { EarWeight } \\
\text { (gm) }\end{array}$ & $\begin{array}{c}\text { Ear Length } \\
(\mathrm{cm})\end{array}$ & \\
\hline \multicolumn{5}{|c|}{ Fertilizer } & \\
\hline No fertilizer & 190.1 & 20.4 & 1.2 & 10.1 & 38.7 \\
\hline $50 \%$ RDF & 208.3 & 27.1 & 1.5 & 14.0 & 40.5 \\
\hline $75 \% \mathrm{RDF}$ & 215.1 & 32.1 & 1.6 & 14.8 & 41.6 \\
\hline $100 \%$ RDF & 220.5 & 36.1 & 1.8 & 15.1 & 42.7 \\
\hline $125 \%$ RDF & 228.6 & 39.6 & 2.4 & 15.6 & 45.2 \\
\hline $\operatorname{SEm}( \pm)$ & 3.1 & 0.3 & 0.1 & 0.1 & 0.40 \\
\hline $\mathrm{CD}(\mathrm{P}=\mathbf{0 . 0 5})$ & 8.9 & 0.8 & 0.2 & 0.4 & 1.16 \\
\hline \multicolumn{5}{|c|}{ Biofertilizer } & \\
\hline No Bio fertilizer & 195.6 & 29.2 & 1.7 & 13.6 & 41.0 \\
\hline PSB & 199.9 & 30.6 & 1.6 & 13.8 & 42.0 \\
\hline Azo & 220.0 & 31.4 & 1.7 & 14.0 & 42.0 \\
\hline PSB+Azo & 233.8 & 33.1 & 1.8 & 14.3 & 42.5 \\
\hline $\operatorname{SEm}( \pm)$ & 2.8 & 0.3 & 0.2 & 0.1 & 0.36 \\
\hline $\mathrm{CD}(\mathrm{P}=\mathbf{0 . 0 5})$ & 7.9 & 0.7 & 0.7 & 0.4 & 1.04 \\
\hline
\end{tabular}

Table.3 Effect nutrient management on yield of wheat

\begin{tabular}{|c|c|c|c|}
\hline \multicolumn{4}{|c|}{ Yield } \\
\hline Treatments & Grain yield (t/ha) & Straw yield (t/ha) & Harvest index (\%) \\
\hline \multicolumn{4}{|c|}{ Fertilizer } \\
\hline No fertilizer & 0.73 & 1.19 & 36.1 \\
\hline $50 \%$ RDF & 1.13 & 1.88 & 37.4 \\
\hline $75 \%$ RDF & 1.84 & 3.14 & 38.2 \\
\hline $100 \% \mathrm{RDF}$ & 2.49 & 3.80 & 39.4 \\
\hline $125 \% \mathrm{RDF}$ & 3.28 & 3.92 & 45.1 \\
\hline $\operatorname{SEm}( \pm)$ & 0.04 & 0.05 & 0.01 \\
\hline $\mathrm{CD}(\mathrm{P}=0.05)$ & 0.12 & 0.14 & 0.02 \\
\hline \multicolumn{4}{|c|}{ Biofertilizer } \\
\hline No Biofertilizer & 1.62 & 2.50 & 38.2 \\
\hline PSB & 1.79 & 2.56 & 39.2 \\
\hline Azo & 1.98 & 2.98 & 38.4 \\
\hline PSB+Azo & 2.19 & 3.11 & 41.4 \\
\hline $\operatorname{SEm}( \pm)$ & 0.04 & 0.04 & 0.01 \\
\hline $\mathrm{CD}(\mathrm{P}=0.05)$ & 0.11 & 0.13 & 0.02 \\
\hline
\end{tabular}


Table.4 Effect nutrient management on nutrient uptake of wheat

\begin{tabular}{|c|c|c|c|}
\hline \multicolumn{4}{|c|}{ Nutrient uptake(kg/ha) } \\
\hline Treatments & Total N uptake & Total P uptake & Total K uptake \\
\hline \multicolumn{4}{|c|}{ Fertilizer } \\
\hline No fertilizer & 15.9 & 4.2 & 14.6 \\
\hline $50 \%$ RDF & 26.8 & 8.0 & 25.8 \\
\hline 75\% RDF & 51.9 & 13.5 & 43.6 \\
\hline $100 \%$ RDF & 70.7 & 17.5 & 55.3 \\
\hline $125 \%$ RDF & 87.1 & 24.5 & 63.8 \\
\hline $\operatorname{SEm}( \pm)$ & 0.4 & 0.1 & 0.4 \\
\hline $\mathrm{CD}(\mathbf{P}=\mathbf{0 . 0 5})$ & 1.3 & 0.4 & 1.2 \\
\hline \multicolumn{4}{|c|}{ Biofertilizer } \\
\hline No Bio fertilizer & 43.0 & 11.5 & 35.4 \\
\hline PSB & 46.8 & 12.1 & 37.0 \\
\hline Azo & 51.4 & 14.6 & 43.5 \\
\hline PSB+Azo & 60.7 & 16.1 & 46.7 \\
\hline $\operatorname{SEm}( \pm)$ & 0.4 & 0.1 & 0.4 \\
\hline $\mathrm{CD}(\mathbf{P}=0.05)$ & 1.1 & 0.3 & 1.1 \\
\hline
\end{tabular}

It may conclude as the nutrient management with combined application of the biofertilizers along with application of $125 \mathrm{~kg} \mathrm{~N}, 62.5 \mathrm{~kg}$ $\mathrm{P}_{2} \mathrm{O}_{5}$ and $62.5 \mathrm{~kg} \mathrm{~K}_{2} \mathrm{O} /$ ha have favourable effect on the growth, productivity and nutrient uptake of wheat in the red and lateritic belt of West Bengal.

\section{References}

Akbari, G. A., Arab, S. M., Alikhani, H. Allahdadi, A. I. and Arzanesh. M. H. 2007. Isolation and selection of indigenous Azospirillum spp. and the IAA of superior strains effects on wheat roots. World Journal of Agricultural Sciences. 3(4): 523-9.

Anonymous.Area and Production. Statistical Year Book India, Ministry of Statistics and Programme Implementation, Government of India, 2018.

http://mospi.nic.in/statistical-year-bookindia/2018/177 on 10-12-2018.

Cochran, W.G. and Cox, G.M. 1977. Exprimental Designs. $1^{\text {st }}$ India Ed. Asia publishing House, Bombay, Calcutta, New Delhi and Madras.

Gruhn, P. and Goletti, F. 1998. The future through 2020. Proceedings of the IFPRI/FAO workshop on plant nutrient management, food security, and sustainable agriculture: Washington, DC, and Rome: IFPRI and FAO.

Jakhar, P., Singh, J. and Nanwal, R. K. 2005. Nutrient content and uptake in wheat (Triticum aestivum L.) as influenced by planting methods, biofertilizers and nitrogen levels. Haryana Journal of Agronomy. 21(1): 75-77.

Kaushik MK, Bishnoi NR, Sumeriya HK. Productivity and economics of wheat as influenced by inorganic and organic sources of nutrients. Annals of Plant and Soil Research. 2012; 14(1):61-64. 5.

Khavazi, K., H. Asadi-Rahmani, and M. J. Malakouti (eds.) 2005. Necessity for the production of biofertilizers in Iran. Tehran, Iran: Soil and Water Research Institute (SWRI). Tehran, Iran. pp: 419. 
Prasad, R. 2008. Integrated plant nutrient supply system (IPNS) for sustainable agriculture. Indian Journal of Fertilisers. 4(12): 71...90.

Rathore, S. A. and Sharma, N. L. 2009. Effect of integrated nutrient management on productivity and nutrient uptake in wheat and soil fertility. Asian Journal of Soil Science. 2009. 4(2): 208-210.

Sepat, R.N., Rai, R. K. and Dhar, S. 2010. Planting systems and integrated nutrient management for enhanced wheat (Triticum aestivum) productivity. Indian Journal of Agronomy. 55(2): 114-118.

Shankar, T., Maitra, S., Sairam, M. and Mahapatra, R. (2020). Influence of integrated nutrient management on growth and yield attributes of summer rice (Oryza sativa L.). Crop Res. $55(1 \& ; 2): 1-5$.

Sikarwar B.S., Reddy, M.D. Pandey,G. and Singh,M. 2020.Response of wheat (Triticum aestivum L.) varieties to different levels of nitrogen under rain fed condition. International Journal of Chemical Studies .8(2): 1293-1296

Singh, G., Kumar,S.,Singh ,S.G. and Kaur,R. 2018. Effect of integrated nutrient management on yield of wheat (Triticum aestivum L.) under irrigated conditions. International Journal of Chemical Studies. 6(2): 904-907

Virmani, S. M. 1994. Effect of inorganic fertilizers on growth and yield of wheat and soil properties. Journal of Indian Social Science. (42):516-519.

\section{How to cite this article:}

Samata Mohanta, Mahua Banerjee and Tanmoy Shankar. 2020. Influence of Nutrient Management on the Growth, Yield and Nutrient Uptake of Wheat (Triticum aestivum. L) in Lateritic Belt of West Bengal. Int.J.Curr.Microbiol.App.Sci. 9(06): 1389-1396. doi: https://doi.org/10.20546/ijcmas.2020.906.173 